\title{
उMR
}

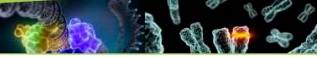

\section{Genetic divergence of common bean cultivars}

\author{
J.S. Veloso ${ }^{1}$, W. Silva ${ }^{1}$, L.R. Pinheiro ${ }^{1}$, J.B. dos Santos ${ }^{1}$, N.S. Fonseca Jr. ${ }^{2}$ \\ and M.P. Euzebio ${ }^{3}$ \\ ${ }^{1}$ Departamento de Biologia, Universidade Federal de Lavras, Lavras, MG, Brasil \\ ${ }^{2}$ Instituto Agronômico do Paraná, Londrina, PR, Brasil \\ ${ }^{3}$ Universidade Estadual de Londrina, Londrina, PR, Brasil \\ Corresponding author: J.V. Veloso \\ E-mail: bio.juveloso@gmail.com
}

Genet. Mol. Res. 14 (3): 11281-11291 (2015)

Received February 23, 2015

Accepted June 12, 2015

Published September 22, 2015

DOI http://dx.doi.org/10.4238/2015.September.22.22

\begin{abstract}
The aim of this study was to evaluate genetic divergence in the 'Carioca' (beige with brown stripes) common bean cultivar used by different institutions and in 16 other common bean cultivars used in the Rede Cooperativa de Pesquisa de Feijão (Cooperative Network of Common Bean Research), by using simple sequence repeats associated with agronomic traits that are highly distributed in the common bean genome. We evaluated 22 polymorphic loci using bulks containing DNA from 30 plants. There was genetic divergence among the Carioca cultivar provided by the institutions. Nevertheless, there was lower divergence among them than among the other cultivars. The cultivar used by Instituto Agronômico do Paraná was the most divergent in relation to the Carioca samples. The least divergence was observed among the samples used by Universidade Federal de Lavras and by Embrapa Arroz e Feijão. Of all the cultivars, 'CNFP 10104' and 'BRSMG Realce' showed the greatest dissimilarity. The cultivars were separated in two groups of greatest similarity using the Structure software. Genetic variation among cultivars was greater than the variation within or between the groups formed. This fact, together with the high estimate of heterozygosity observed and the genetic divergence of the samples of the Carioca cultivar in relation to the original provided by Instituto
\end{abstract}


Agronômico de Campinas, indicates a mixture of cultivars. The high divergence among cultivars provides potential for the utilization of this genetic variability in plant breeding.

Key words: Phaseolus vulgaris; Mixture of cultivars; Genetic purity; Microsatellite markers; Simple sequence repeat; Genetic dissimilarity

\section{INTRODUCTION}

Genetic divergence among cultivars is very important for the genetic breeding of crops. It forms a basis for the protection of intellectual property, and against the possible occurrence of environmental problems that may make the use of current elite cultivars unviable. Knowledge of genetic diversity is applied with a view to produce new cultivars, such as the use of backcrossing in genetic breeding programs, and may provide information about the stability of cultivar samples that are used over many years by different institutions. Knowledge of cultivar stability may indicate the need to alter their diversity in future breeding programs or suggest procedures for cultivar maintenance.

In Brazil, common bean (Phaseolus vulgaris L.) is commonly consumed and produced, and might be considered part of Brazilian culture. According to the Ministry of Agriculture (Brasil, 2014), the mean annual production of common bean is 3.5 million tons, and internal consumption is expected to grow by around $1.22 \%$ per year between $2009 / 2010$ and 2019/2020. Large production of this fabaceae member in Brazilian territory is mainly attributed to technological innovations in crop management and the production of cultivars better adapted to the different Brazilian producing regions. This allows broad edaphic and climatic adaptation of the crop, which, according to the State Office for Food and Agriculture, permits cultivation throughout the year in almost all Brazilian states (Secretaria de Estado da Agricultura e Abastecimento, 2013).

Microsatellite markers are important tools used to characterize genotypes. They have co-dominant inheritance, a broad distribution in the genome, and a high rate of polymorphism, they are reproducible (Schuster et al., 2004; Andrade et al., 2013), and they can identify quantitative trait loci (QTL) of important traits. Therefore, these markers have been widely used in studies of genetic diversity in various plant species, such as common bean, soybean, and wheat (Schuster et al., 2009; Vieira et al., 2009; Cardoso et al., 2014).

The aim of this study was to estimate genetic divergence of the 'Carioca' (beige with brown stripes) cultivar used by different institutions, and of other cultivars used in the Rede Cooperativa Sul Brasileira de Pesquisa de Feijão (Southern Brazil Cooperative Network for Common Bean Research), using microsatellite markers associated with QTL of agronomic traits with broad distribution in the common bean genome.

\section{MATERIAL AND METHODS}

The genotypes used consisted of 16 common bean cultivars used in the Rede Cooperativa Sul Brasileira de Pesquisa de Feijão (Tables 1 and 2). Since the Carioca cultivar is very old, cross pollination or naturally occurring mutations may have been sufficient to alter the genetic base of the Carioca common bean population over time. For that reason, the present study evaluated Carioca cultivar samples used in four different Brazilian research 
institutions: the Instituto Agronômico do Paraná, PR; the Universidade Federal de Lavras, MG; the Instituto Agronômico de Campinas, São Paulo; and Embrapa Arroz e Feijão, GO, to verify the possible genetic distance compared to the original cultivar obtained from the Instituto Agronômico de Campinas.

Table 1. Common bean cultivars used in molecular characterization, breeding institution, and commercial type.

\begin{tabular}{lll}
\hline Cultivar & Breeding institution & Commercial type \\
\hline CNFP10104 & CNPAF & Black \\
BRS MG Realce & CNPAF & Streaked \\
Pérola & CNPAF & Carioca \\
BRS Campeiro & CNPAF & Black \\
TB 02-07 & CPACT & Black \\
TB 02-24 & CPACT & Red \\
CHC $01-175$ & EPAGRI & Carioca \\
CHP $98-66-20$ & EPAGRI & Black \\
SM 1107 & FEPAGRO & Black \\
SM 1810 & FEPAGRO & Black \\
P5-4-3-1 & IAC & Carioca \\
PR-14-2-3-2 & IAC & Black \\
LP 07-80 & IAPAR & Carioca \\
LP 08-90 & IAPAR & Black \\
IPR Tangará & IAPAR & Carioca \\
Uirapuru & IAPAR & Black \\
Carioca & IAPAR & Carioca \\
Carioca & IAC & Carioca \\
Carioca & UFLA & Carioca \\
Carioca & CNPAF & Carioca \\
\hline
\end{tabular}

CNFAF = EMBRAPA Arroz e Feijão; CPACT = Centre for Process Analytics and Control Technology; EPAGRI = Empresa de Pesquisa Agropecuária e Extensão Rural de Santa Catarina; FEPAGRO = Fundação Estadual de Pesquisa Agropecuária; IAC = Instituto Agronômico de Campinas; IAPAR = Instituto Agronômico do Paraná; and UFLA = Universidade Federal de Lavras.

Table 2. Genealogy of the common bean cultivars used in molecular characterization and the supplying institution.

\begin{tabular}{|c|c|c|}
\hline Cultivar & Genealogy of the cultivar & Supplying institution \\
\hline CNFP $10104 * *$ & FT85-113 / POT51 & IAPAR \\
\hline BRSMG Realce** & PR 95105259 / PR 93201472 & IAPAR \\
\hline Pérola** & Selection in the Aporé cultivar & IAPAR \\
\hline BRS Campeiro** & Mutation induction program for the Corrente cultivar by gama radiation & IAPAR \\
\hline TB $02-07 * *$ & BRS Expedito x A55 & IAPAR \\
\hline TB $02-24 * *$ & Individual plant selection in a native cultivar & IAPAR \\
\hline CHC $01-175^{* *}$ & BRS Campeiro X IAC Eté & IAPAR \\
\hline CHP 98-66-20** & (Ci 9661 X FT Nobre) + (Ci 9661 X Ci 667/2V) & IAPAR \\
\hline SM $1107 * *$ & (IPR Uirapuru) x (BR Fepagro 44 Guapo Brilhante) & IAPAR \\
\hline SM $1810^{* *}$ & (IPR Uirapuru) x (BR Fepagro 44 Guapo Brilhante) & IAPAR \\
\hline P5-4-3-1** & $\{[$ IAC Carioca Eté x (IAC Carioca Eté x Carioca Precoce) $]$ x Preto 60 Dias $\}$ & IAPAR \\
\hline PR-14-2-3-2** & BRS Supremo x IAC Tunã & IAPAR \\
\hline LP $07-80^{* *}$ & $\begin{array}{l}\{[\text { CNF86-9 x (IAPAR14x Sel. Carioca 80) x BAT 93] x (Sel Carioca } 99 \text { x } \\
\text { Great North Nebrasca } 1 \text { sel 27) x Seleção Aruana }\} \text { x }\{[(\text { Sel. Carioca } 99 \text { x } \\
\text { Great North Nebrasca } 1 \text { sel 27) x (Rai } 46 \text { x (Moruna x G. N. } 1 \text { sel 27) x } \\
\text { Iguaçu) X BAT 93] x [(IAPAR } 14 \text { x IAPAR 31) x BAT 93] x Sel Carioca } \\
99 \times \text { Great North Nebrasca } 1 \text { sel 27 }\}\end{array}$ & IAPAR \\
\hline LP $08-90 * *$ & Unknown & IAPAR \\
\hline IPR Tangará** & (LP 95-92 descendant of IAPAR 31) X (Pérola) & IAPAR \\
\hline Uirapuru** & BAC29/PR1711/3/NEP2/2/PUEBLA 173/ICAPIJAO & IAPAR \\
\hline Carioca* & Selection in producers' crops & IAPAR \\
\hline Carioca* & Selection in producers' crops & IAC \\
\hline Carioca* & Selection in producers' crops & UFLA \\
\hline Carioca* & Selection in producers' crops & EMBRAPA \\
\hline
\end{tabular}

*Küpper et al. (2011). **Information from the IAPAR breeder Dr. Nelson da Silva Fonseca Júnior. 
DNA was extracted according to the procedures reported by Pereira et al. (2007), using approximately $2 \mathrm{~g}$ young leaves from 30 plants of each cultivar. A bulk sample was prepared for each cultivar from the extracted DNA. The number of genotypes constituting the bulks was defined experimentally by Schuster et al. (2004) in soybean. These authors showed that different alleles could be identified in a bulk DNA mixture up to a ratio 1:7 (one contaminating genotype for seven pure genotypes). Bulks were prepared using the DNA of 30 plants from each crop, with the aim of identifying SSR alleles with a frequency of at least $15 \%$ (Schuster et al., 2004). The mixtures observed in relation to seed appearance in each cultivar were eliminated been kept only those that look the patternPrimer pairs were selected based on their distribution on the chromosome map of common bean and on the trait associated with the locus marked by the primer in question (Table 3). This allows genetic divergence to be analyzed taking into account information from the different linkage groups that constitute the common bean genome, thus increasing the efficiency of the estimate of divergence. By selecting primers associated with QTLs of interest, genetic divergence could be characterized in relation to traits of interest in breeding programs.

\begin{tabular}{lll}
\multicolumn{2}{l}{ Table 3. Name of the marker, associated trait, and source. } \\
\hline Name of marker & Associated trait & Source \\
\hline ATA 6 & White mold & Antonio (2012) \\
ATA 7 & White mold & Antonio (2012) \\
BM 141 & Angular leaf spot & Teixeira et al. (2005) \\
BM 143 & Angular leaf spot & Teixeira et al. (2005) \\
BM 154 & Yield & Rodrigues and Santos (2006) \\
BM 170 & Unknown & \\
BM184 & White mold, flowering period, 100 seed weight & Blair et al. (2006) and Soule et al. (2011) \\
BM 185 & Unknown & Cabral et al. (2011) \\
BM 187 & White mold, flowering period, number of seeds per plant & Blair et al. (2006) \\
BM 201 & Angular leaf spot & Teixeira et al. (2005) \\
BMc 94 & White mold & Lara et al. (2014) \\
PvBR13 & Unknown & \\
PvBR35 & Seed Darkening & Couto et al. (2010) \\
PV141 & Cooking Time & Nhanengue (2014) \\
PvBR005 & Unknown & \\
PvBR025 & Unknown & \\
PVESTBR_98 & Seed Darkening & Couto et al. (2010) \\
PVESTBR_42 & White mold & Antonio (2012) \\
PVESTBR_204 & White mold & Lara et al. (2014) \\
PVM02TC116 & Seed Darkening, White mold & Couto et al. (2010) \\
PVM04 TC323 & Blight & Couto et al. (2010) \\
X74919 & Yield & Cabral et al. (2011) \\
\hline
\end{tabular}

PCR reactions were then carried out to evaluate the segregation pattern arising from amplification of the primers among the populations under study. For each reaction, we used 20 ng DNA, $100 \mu \mathrm{M}$ of each dNTP, 1 U Taq DNA polymerase, buffer composed of $50 \mathrm{mM}$ Tris $\mathrm{pH} 8.3,20 \mathrm{mM} \mathrm{KCl}, 2 \mathrm{mM} \mathrm{MgCl}, 10 \mu \mathrm{g} \mathrm{BSA}, 0.25 \%$ Ficoll 400, $10 \mathrm{mM}$ tartrazine, and pure water. The final volume for each reaction was $12 \mu \mathrm{L}$. The reactions were carried out according to the following program: $2 \mathrm{~min}$ at $95^{\circ} \mathrm{C}$ for denaturation, followed by 32 cycles of denaturation of $94^{\circ} \mathrm{C}$ for $20 \mathrm{~s}$, annealing for $20 \mathrm{~s}$ at $46^{\circ}-68^{\circ} \mathrm{C}$, and extension at $72^{\circ} \mathrm{C}$ for $60 \mathrm{~s}$.

The amplification products were subjected to vertical electrophoresis on $8 \%$ polyacrylamide gels that were stained with silver nitrate. Fragments of different sizes were considered different alleles. In this study, the loci at which the most common allele had a frequency of less than $95 \%$ were considered polymorphic (Cole, 2003). 
Genotyping was carried out using 22 polymorphic SSRs in the 20 cultivars analyzed that exhibited clearly resolved bands in polyacrylamide gel.

Genetic diversity was characterized by estimates of allele frequency, mean number of alleles per locus, number of effective alleles per locus, observed heterozygosity $\left(H_{\mathrm{O}}\right)$, expected heterozygosity $\left(H_{\mathrm{E}}\right)$, and polymorphic information content (PIC).

Genetic divergence among the cultivars was estimated using the complement of the weighted similarity coefficient (Cruz et al., 2011). Cluster analysis was carried out by the unweighted pair group method with arithmetic mean (UPGMA). The cophenetic correlation coefficient (CCC) was established from the Pearson linear correlation between the elements of the cophenetic matrix and the elements of the dissimilarity matrix (Cargnelutti-Filho et al., 2010).

The population structure was evaluated from the estimates of kinship among the 20 cultivars (Table 1) using the Structure Harvester software (Earl and von Holdt, 2012) based on analysis of the heterogeneity of distribution of the cultivars among groups of greatest similarity, using the Structure v. 2.3.2 software (Pritchard et al., 2000) and through analysis of molecular variance (AMOVA) as proposed by Excoffier et al. (1992).

\section{RESULTS AND DISCUSSION}

All 22 loci contained alleles with a frequency lower than 95\% and were therefore considered polymorphic (Figure 1).

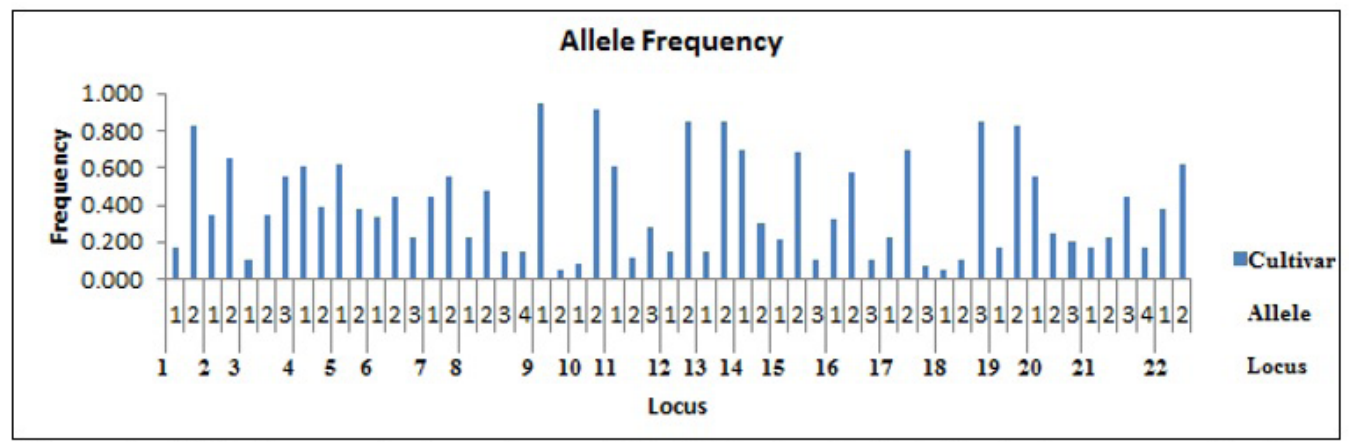

Figure 1. Allele frequencies in each one of the 22 loci evaluated. The loci correspond to the regions marked by the primers shown in Table 3, respectively.

The 22 primers evaluated amplified 56 alleles, with a mean 2.5 alleles per locus (Table 4). There was variation of 2-4 alleles per locus, with the primers PvBR25 and ATA6 being the most informative (Table 4). Cardoso et al. $(2013,2014)$ found a mean number of alleles per locus greater than that seen in the present study. In 2013, the authors evaluated the genetic divergence of 172 common bean lines and cultivars making up five VCU trials conducted by the genetic breeding program of Embrapa Arroz e Feijão using 30 pairs of polymorphic primers. In that study, an average of 7.79 alleles per locus was observed. In 2014, the same authors obtained an average of 8.29 alleles per locus in a study of genetic divergence of 157 commercial common bean cultivars using 24 polymorphic primers. In this study, an average number of alleles per locus less than the numbers presented by the 
authors was observed, probably because of the smaller number of genotypes evaluated and the greater kinship among them.

Table 4. Indices of genetic diversity and inbreeding of the 20 common bean cultivars evaluated using 22 SSR loci.

\begin{tabular}{lccccc}
\hline Marker & $N_{\mathrm{A}}$ & $N_{\mathrm{E}}$ & $H_{\mathrm{O}}$ & $H_{\mathrm{E}}$ & PIC \\
\hline X74919 & 2.000 & 1.406 & 0.150 & 0.289 & 0.289 \\
PV141 & 2.000 & 1.835 & 0.100 & 0.455 & 0.455 \\
PVESTBR_204 & 3.000 & 2.299 & 0.000 & 0.565 & 0.565 \\
BM143 & 2.000 & 1.906 & 0.222 & 0.475 & 0.475 \\
BM170 & 2.000 & 1.882 & 0.250 & 0.469 & 0.469 \\
PVESTBR_98 & 3.000 & 2.793 & 0.000 & 0.642 & 0.643 \\
PvBR35 & 2.000 & 1.980 & 0.800 & 0.495 & 0.495 \\
PvBR25 & 4.000 & 3.113 & 0.150 & 0.679 & 0.679 \\
BM154 & 2.000 & 1.105 & 0.100 & 0.095 & 0.095 \\
BM184 & 2.000 & 1.170 & 0.053 & 0.145 & 0.146 \\
BM 187 & 3.000 & 2.160 & 0.000 & 0.537 & 0.255 \\
BMc94 & 2.000 & 1.342 & 0.300 & 0.255 & 0.255 \\
BM185 & 2.000 & 1.342 & 0.000 & 0.255 & 0.420 \\
PVM04 TC323 & 2.000 & 1.724 & 0.200 & 0.420 & 0.477 \\
PvBR5 & 3.000 & 1.910 & 0.000 & 0.476 & 0.554 \\
BM141 & 3.000 & 2.241 & 0.050 & 0.554 & 0.265 \\
PvBR13 & 3.000 & 1.831 & 0.100 & 0.454 & 0.289 \\
PVM02 TC116 & 3.000 & 1.361 & 0.100 & 0.265 & 0.595 \\
BM201 & 2.000 & 1.406 & 0.050 & 0.289 & 0.699 \\
ATA7 & 3.000 & 2.469 & 0.000 & 0.595 & 0.472 \\
ATA6 & 4.000 & 1.306 & 0.000 & 0.698 & 0.436 \\
PVESTBR_42 & 2.000 & 1.931 & 0.122 & 0.435 & \\
Mean & 2.545 & & & & \\
\hline
\end{tabular}

$N_{\mathrm{A}}=$ total number of alleles; $N_{\mathrm{E}}=$ effective number of alleles; $H_{\mathrm{O}}=$ observed heterozygosity; $H_{\mathrm{E}}=$ expected heterozygosity, and PIC = polymorphic information content.

The effective number of alleles per locus ranged from 1.105 to 3.306 , with the mean number being 1.931 (Table 4). This estimate was less than the mean number of alleles per locus, indicating the presence of rare alleles, probably resulting from a varietal mixture or cross-pollination.

The observed heterozygosity was less than the expected heterozygosity in loci of an ideal population for most of the loci analyzed (Table 4). The observed heterozygosity ranged from 0.000 to 0.800 with a mean value of 0.122 . The expected heterozygosity ranged from 0.095 to 0.698 with a mean value of 0.435 . This result indicates an excess of homozygosis for most of the loci evaluated in relation to an ideal population. As common bean is an autogamous plant, it was expected that the observed heterozygosity per locus would be less than the expected heterozygosity for all loci. Nevertheless, this did not occur, probably due to the occurrence of a varietal mixture or cross pollination in the experimental stations of the institutions supplying the cultivars. It is necessary to consider, however, that in various SSR loci in common bean, there is heterozygosis even after 24 generations of self-pollination (Rodrigues and dos Santos, 2006).

In general, the discriminatory power of the loci analyzed (PIC) was considered moderately informative, ranging from 0.095 to 0.699 , with a mean value of 0.436 (Table 4).

The complement of the weighted similarity coefficient calculated to estimate the dissimilarities among the cultivars ranged from 0.0357 to 0.8125 (Figure 2). The cophenetic correlation coefficient between the graph distances and the dissimilarity data shown in 
the dendrogram was $83 \%(\mathrm{CCC}=0.8343)$. This estimate indicates high reliability in representation of the dissimilarity data by the dendrogram. The lowest estimate was found between the Carioca cultivars supplied by UFLA and the one supplied by EMBRAPA Arroz e Feijão (CNPAF). This was expected since the cultivar used by UFLA was originally a seed sample supplied by EMBRAPA Arroz e Feijão, which was later multiplied at the university. The greatest value of genetic dissimilarity was found between the cultivars CNFP 10104 and BRS MG Realce, which belong to different commercial types and genetic groups, Black/ Mesoamerican and Streaked/Andean, respectively. Additionally, cultivar LP 07-80, which is of the Carioca commercial type, is one of the most divergent as compared to the other cultivars studied (Table 2 and Figure 2). This wide divergence may be due to its origin, since a great number of genotypes were crossed, including the cultivar 'Great Northern', obtained in North America (Table 2). Consequently, LP 07-80 contains more allelic diversity, and if it has promise for growing, it will certainly have promise as a parental line in breeding programs.

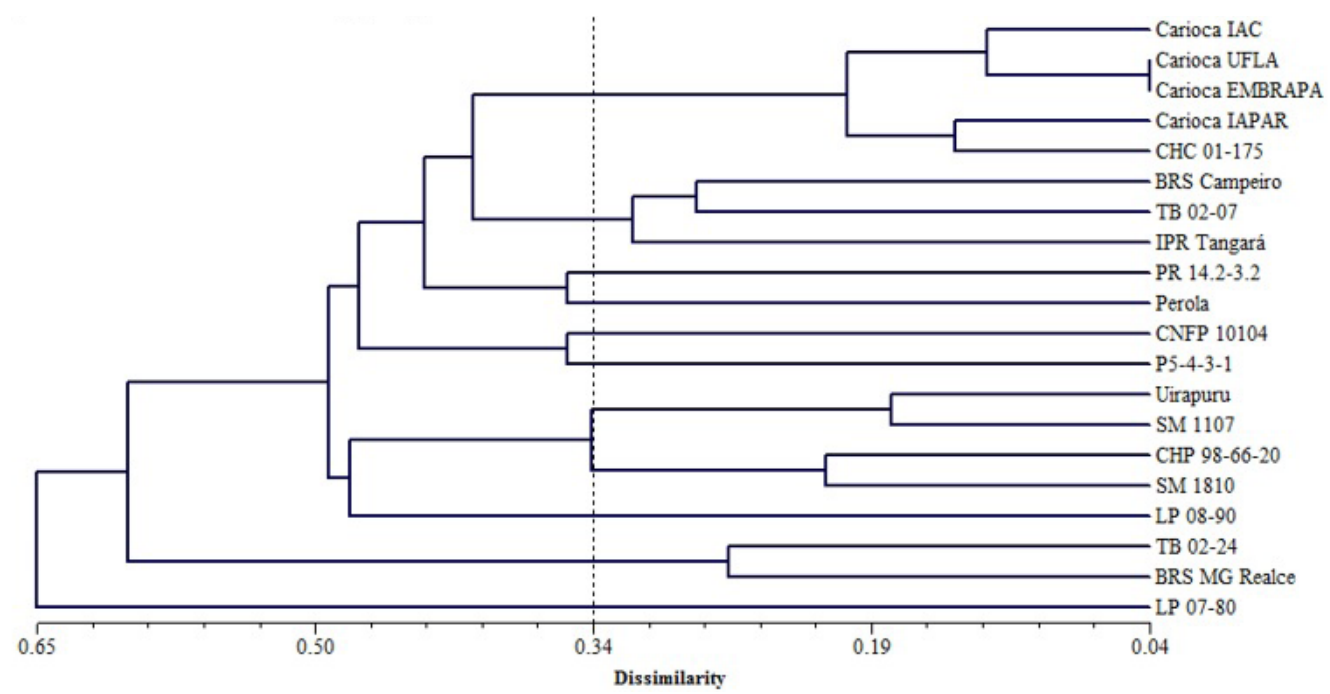

Figure 2. Dendrogram generated by the UPGMA method through the dissimilarity matrix among the 20 common bean cultivars evaluated.

With the help of the dendrogram obtained, it is also possible to observe the genetic divergence among the 'Carioca' cultivars supplied by the institutions. This divergence between samples may be used during genetic breeding. The 'Carioca' cultivar supplied by the CNPAF and the one supplied by UFLA were the least divergent. Nevertheless, they showed divergence in relation to the cultivar supplied by IAC, which is considered to be the standard, because according to the Coordenadoria de Assistência Técnica Integral (Office of Integral Technical Assistance), the original 'Carioca' cultivar was identified and released by the IAC. The 'Carioca' cultivar supplied by the IAPAR showed similarity to the cultivar CHC 01-175, and it was considered the most divergent among the 'Carioca' cultivar samples evaluated. Nevertheless, the different samples of the 'Carioca' cultivar are not highly divergent when compared to the other cultivars. Similarity of the cultivar CHC 01-175 to the 'Carioca' 
supplied by IAPAR is due to genealogy since the parent of the cultivar CHC 01-175 was 'IAC Eté', which belongs to the Carioca commercial type.

Considering that 50-100 fragments of amplified DNA are sufficient to estimate genetic relationships between and among populations of plant species (Colombo et al., 2005), the 56 fragments used in this study may have been sufficient to effectively estimate the genetic divergence among cultivars.

The results of bootstrap analyses carried out using 56 fragments of 20 cultivars are shown in Table 5. With 21 markers, it is possible to represent the genetic divergence among the accessions as satisfactory as with the 22 markers since the estimate of mean stress is less than $0.05 \%$. Therefore, the correlation between the measures of divergence obtained using 22 markers was greater than $0.95 \%$ and indicates that a satisfactory number was used in the study.

Table 5. Bootstrap analysis for identification of the optimum number of markers from evaluation of mean stress.

\begin{tabular}{lc}
\hline No. of markers & Mean stress \\
\hline 1 & 0.8582 \\
3 & 0.4866 \\
5 & 0.3604 \\
7 & 0.2853 \\
9 & 0.2357 \\
1 & 0.1962 \\
13 & 0.1631 \\
15 & 0.1341 \\
17 & 0.1063 \\
19 & 0.0774 \\
21 & 0.0413 \\
\hline
\end{tabular}

Through the population structure analysis implemented by the Structure software, the cultivars were separated into two groups of greatest genetic similarity (Figure 3).

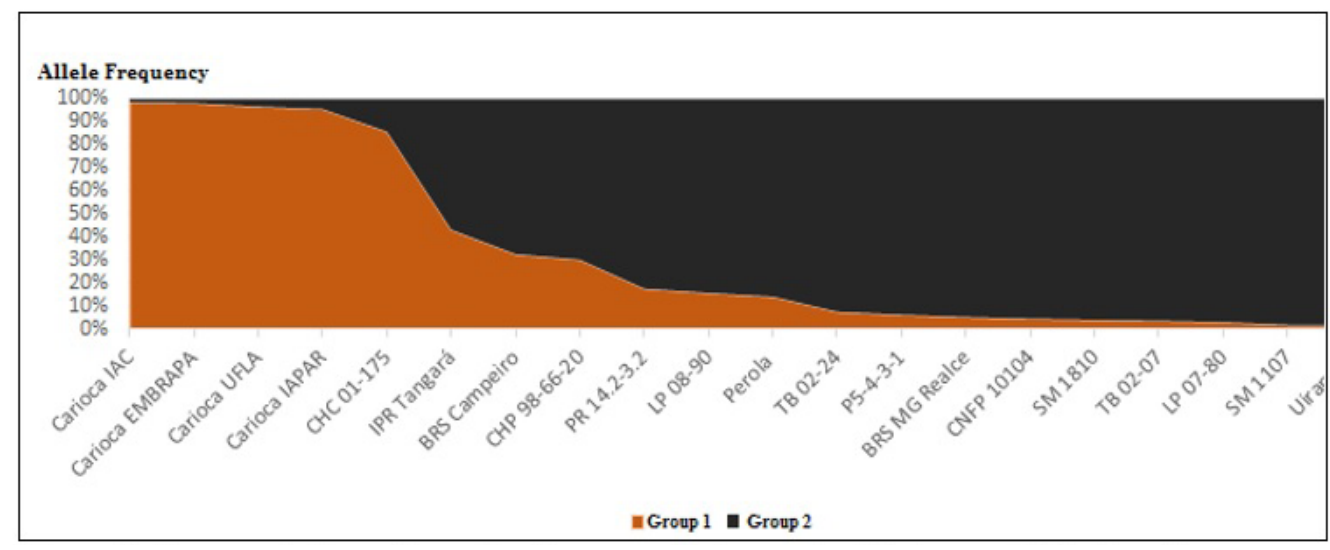

Figure 3. Representation of genetic divergence between the Carioca and Black cultivars.

Group 1 comprised most of the Carioca commercial type cultivars, and Group 2 comprised the Black commercial type cultivars. Nevertheless, there were Carioca type cultivars 
that had greater similarity to those of the Black type and vice-versa. This indicates the existence of alleles that are characteristic of one group that may also be found in another group because of kinship between cultivars in both groups. During the breeding process, crosses were made using parents of the two commercial groups (Black and Carioca) to associate favorable alleles from both (Table 1). The cultivars BRS MG Realce and TB 02-24, belonging to the Streaked and Red commercial types respectively, probably contain SSR alleles that are most similar to those of the Black group. Among these alleles, there may be QTLs of agronomic traits (Table 3).

It should be noted that in Figure 3, the location of the cultivar LP 07-80 is closer to the Black group, even though it belongs to the Carioca commercial type. This may be explained by the fact that it has Andean parents, just as BRS MG Realce and Great Northern Nebraska 1. sel. 27.

Additionally, the kinship observed may also be due, in part, to the cultivars having loci in heterozygosis $\left(H_{\mathrm{O}}\right)$ in an amount greater than expected for autogamous plants, at least partially reflecting the occurrence of a mixture and the heterozygosis maintained through natural selection in autogamous plants like common bean (Rodrigues and dos Santos, 2006) (Table 4). This may also be observed in the dendrogram (Figure 2). Few loci in heterozygosis were expected because the improved common bean cultivars are derived from crossing different parents, and in the segregating population, a generation $\mathrm{F}_{2}$ plant or derivative is selfpollinated, which generates a progeny. The progenies obtained in this manner are successively self-pollinated and the best progeny that will constitute a new cultivar is selected. Therefore, it is expected that each cultivar be composed of a mixture of lines.

Considering the two groups formed, analysis of molecular variance was carried out (Figure 4). Accordingly, genetic divergence between cultivars (61\%) is greater than the divergence between the Carioca and Black groups (12\%) and the divergence within each cultivar (27\%). Considering that common bean is an autogamous plant, less divergence within cultivars was expected. This estimate, together with the high values of heterozygosity, indicates a mixture of lines in each cultivar as well as heterozygosis. The divergence among cultivars is quite marked, even in this set of only 20 already improved cultivars, indicating that they have lower vulnerability than may be seen in relation to pathogen resistance in soybean. Moreover, it indicates considerable variability among these improved cultivars, which might be manipulated in breeding programs.

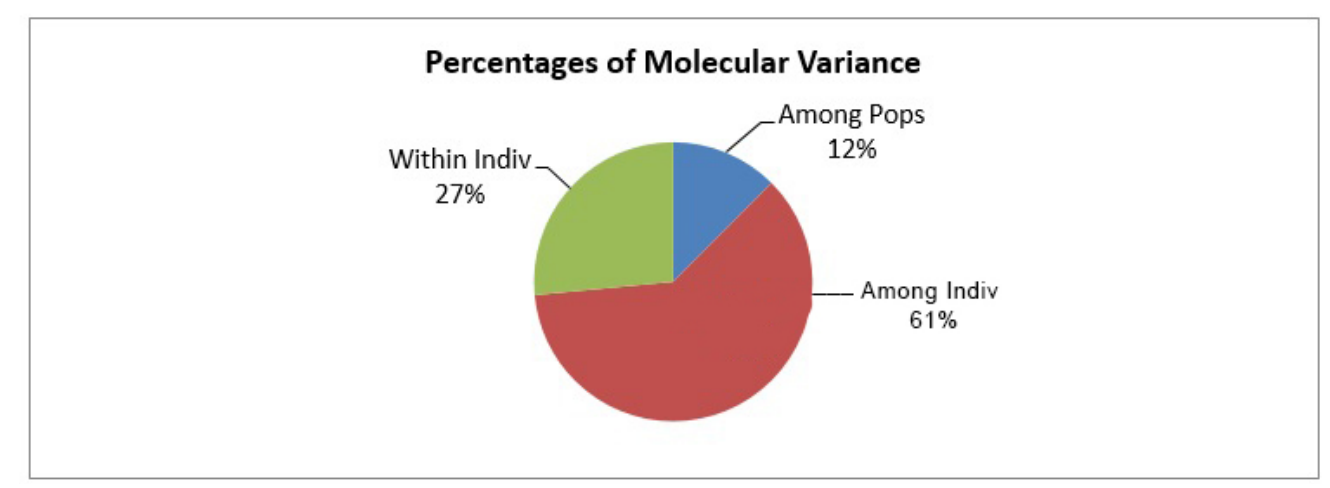

Figure 4. Representation of genetic divergence among and within cultivars and between the Carioca and Black groups. 
Among the Carioca cultivars, those of UFLA and EMBRAPA Arroz e Feijão are the most similar (0.03571), whereas the one used in IAPAR has the greatest difference. Nevertheless, the Carioca cultivar samples have greater similarity between themselves than in relation to the other cultivars.

Among the cultivars studies, CNFP 10104 and BRS MG Realce showed the greatest difference (0.8125), which was probably due to them belonging to different commercial types and genetic groups, Black/Mesoamerican and Streaked/Andean, respectively.

The heterozygosity observed was higher than expected for autogamous plants $(0.05)$, indicating a mixture of lines and, in part, heterozygosity maintained by natural selection. Nevertheless, the cultivars studied show greater genetic variation among cultivars than within cultivars or between the Carioca and Black groups. Cluster analyses were effective for separating the cultivars into groups of greater genetic similarity; however, there was no formation of groups defined that separated the Carioca commercial type from the Black commercial type, because of the origin of the cultivars and of the markers used.

\section{Conflicts of interest}

The authors declare no conflict of interest.

\section{ACKNOWLEDGMENTS}

CNPq for funding the molecular analysis and for the scholarship to J.V. Veloso.

\section{REFERENCES}

Andrade MT, Santos JB, Fonseca Jr NS and Veloso JS (2013). Paternity test for IAPAR 139 cultivar of common bean. Annu. Rep. Bean Improv. Coop. 56: 161-162.

Antonio RP, Dos Santos JB, Alves FC, Carvalho PB, et al. (2012). Seleção assistida por marcadores de DNA em retrocruzamento visando resistência ao mofo branco em feijoeiro. Rev. Caatinga 25: 61-67.

Blair MW, Iriarte G and Beebe S (2006). QTL analysis of yield traits in an advanced backcross population derived from a cultivated Andean X wild common bean (Phaseolus vulgaris L.) cross. Theor. Appl. Genet. 112: 1149-1163.

Brasil Ministério da Agricultura: Perfil do feijão no Brasil (2014). Available at [http://www.agricultura.gov.br/vegetal/ culturas/feijao/saiba-mais]. Accessed March 20, 2013.

Cabral PD, Soares TC, Lima AB, de Miranda FD et al. (2011). Genetic diversity in local and commercial dry bean (Phaseolus vulgaris) accessions based on microsatellite markers. Genet. Mol. Res. 10: 140-149.

Cardoso PC, Veiga MM, de Menezes IP, Valdisser PA, et al. (2013). Molecular characterization of high performance inbred lines of Brazilian common beans. Genet. Mol. Res. 12: 5467-5484.

Cardoso PC, Brondani C, Menezes IP, Valdisser PA, et al. (2014). Discrimination of common bean cultivars using multiplexed microsatellite markers. Genet. Mol. Res. 13: 1964-1978.

Cargnelutti-Filho AC, Ribeiro ND and Burin C (2010). Consistência do padrão de agrupamento de cultivares de feijão conforme medidas de dissimilaridade e métodos de agrupamento. Pesq. Agropec. Bras. 45: 236-243.

Cole CT (2003). Genetic variation in rare and common plants. Annu. Rev. Ecol. Evol. Syst. 34: 213-237.

Colombo LA, de Faria RT, de Assis AM, de Batista Fonseca IC, et al. (2005). Aclimatação de um híbrido de Cattleya em substratos de origem vegetal sob dois sistemas de irrigação. Acta Sci. Agron. 27: 145-150.

Couto KR, dos Santos JB, Ramalho MAP and da Silva GS (2010). Identification of microsatellite markers associated with seed-coat darkening in common bean. Pesq. Agropec. Bras. 45: 1268-1274.

Cruz CD, Ferreira FM and Pessoni LA (2011). Biometria aplicada ao estudo da diversidade genética. Universidade Federal de Viçosa, Viçosa.

Earl DA and von Holdt BM (2012). Structure Harvester: a website and program for visualizing structure output and implementing the Evanno method. Conserv. Genet. Resour. 4: 359-361. 
Excoffier L, Smouse PE and Quattro JM (1992). Analysis of molecular variance inferred from metric distances among DNA haplotypes: application to human mitochondrial DNA restriction data. Genetics 131: 479-491.

Küpper Cardoso Perseguini JM, Chioratto AF, Zucchi MI, Colombo CA, et al. (2011). Genetic diversity in cultivated carioca common beans based on molecular marker analysis. Genet. Mol. Biol. 34: 88-102.

Lara LA de C, dos Santos JB, Veloso JS, Balestre M, et al. (2014). Identification of QTLs for resistance to Sclerotinia sclerotiorum in carioca common bean by the moving away method. ISRN Microbiol. 2014: 1-7.

Nhanengue CL, Alves FC, Pinheiro LR, Leite ME, et al. (2014). Estimates of genetic and phenotypic parameters of common bean cooking time. Annu. Rep. Bean Improv. Coop. 57: 197-198.

Pereira HS, dos Santos JB, Abreu AFB and Couto KR (2007). Informações fenotípicas e marcadores microssatélites de QTL na escolha de populações segregantes de feijoeiro. Pesq. Agropec. Bras. 42: 707-713.

Pritchard JK, Stephens M and Donelly P (2000). Inference of population structure using multilocus genotype data. Genetics 155: 945-959.

Rodrigues TB and dos Santos JB (2006). Effect of natural selection on common bean (Phaseolus vulgaris) microsatellite alleles. Genet. Mol. Biol. 29: 345-352.

Salvador Secretaria de Estado da Agricultura e do Abastecimento: Feijão - Análise da conjuntura agropecuária (2013). Available at [http://www.agricultura.pr.gov.br/arquivos/File/deral/Prognosticos/feijao_2013_14]. Accessed November 6, 2014.

Schuster I, Queiroz VT, Teixeira AI, Barros EG, et al. (2004). Determinação da pureza varietal de sementes de soja com o auxílio de marcadores moleculares microssatélites. Pesq. Agropec. Bras. 39: 247-253.

Schuster I, Vieira ES, da Silva GJ, de Assis Franco F, et al. (2009). Genetic variability in Brazilian wheat cultivars assessed by microsatellite markers. Genet. Mol. Biol. 32: 557-563.

Soule M, Porter L and Miklas PN (2011). Comparative QTL map for white mold resistance in common bean, and characterization of partial resistance in dry bean lines VA19 and I9365-31. Crop Sci. 51: 123-139.

Teixeira FF, dos Santos JB, Ramalho MAP, de Fatima Barbosa Abreu, et al. (2005). QTL mapping for angular leaf spot in common bean using microsatellite markers. Crop Breed. Appl. Biot. 5: 272-278.

Vieira ESN, Schuster I, Silva SB and Oliveira MAR (2009). Variabilidade genética em cultivares de soja determinada com marcadores microssatélites em gel de agarose. Pesq. Agropec. Bras. 44: 1460-1466. 